\title{
PENGARUH PENGALAMAN KERJA TERHADAP MOTIVASI KERJA PEGAWAI PADA DINAS PERUMAHAN DAN PERMUKIMAN KABUPATEN LAMPUNG SELATAN
}

\author{
Rusli Mohammad Asri( ${ }^{(1)}$, Kisro Eddy ${ }^{(2)}$, Raditte Husin ${ }^{(3)}$ \\ Fakultas Ekonomi Universitas Sang Bumi Ruwa Jurai \\ rusli.m_asri@gmail.com,kisro.eddy@fe.saburai.ac.id,raditte.husin@fe.saburai.ac.id
}

\begin{abstract}
Abstrak. Permasalahan dalam penelitian ini masih banyak pegawai yg belum perpengalaman, dan pegawai yang belum memiliki kemampuan dan pengetahuan yang memadai untuk mengerjakan pekerjaan seharihari serta menurunnya motivasi kerja pegawai terhadap kinerja di Dinas Perumahan Dan Permukiman Kabupaten Lampung Selatan. Tujuan penelitian ini untuk mengetahui pengaruh pengalaman kerja terhadap motivasi kerja pegawai pada Dinas Perumahan Dan Permukiman Kabupaten Lampung Selatan. Pengumpulan data yang digunakan berupa data primer dan data sekunder. Teknik pengumpulan data yang digunakan adalah observasi, wawancaraa, dokumentasi dan quisioner/ daftar pertanyaan. Teknik sampel akan ditentukan dari jumlah populasi sebanyak 60 orang responden pegawai Dinas Perumahan dan Permukiman Kabupaten Lampung Selatan. Berdasarkan analisa kuantitatif diperoleh dari hasil perhitungan yaitu pengaruh Pengalaman Kerja (X) terhadap Motivasi Kerja (Y) secara parsial menunjukan bahwa Nilai t hitung variabel pengalaman kerja yaitu 3.364 dan $t$ tabel 1.671 karena $t$ hitung $>t$ tabel maka Ha diterima artinya Pengalaman kerja berpengaruh positif terhadap motivasi kerja pegawai Dinas Perumahan dan Permukiman Kabupaten Lampung Selatan. Kontribusi ( $R$ Square ) sebesar 0.163 artinya sebesar $16,3 \%$ variasi perubahan variabel motivasi kerja mampu dijelaskan oleh variabel pengalaman kerja.
\end{abstract}

Kata kunci: Kerja, Kuantitatif, Motivasi, Pengalaman.

\section{PENDAHULUAN}

Keberadaan sumber daya manusia di dalam suatu organisasi memegang peranan sangat penting. Sebagai Intellectual Capital, karyawan memiliki tugas yang besar untuk menjalankan aktivitas organisasi agar produktivitas kerja yang diharapkan oleh organisasi tercapai. Produktivitas tenaga kerja merupakan suatu ukuran sampai sejauh mana manusia atau angkatan kerja dipergunakan dengan baik dalam suatu proses produksi untuk mewujudkan hasil (output) yang diinginkan.

Oleh karena itu, dibutuhkan tenaga kerja yang profesional / kompetitif supaya perusahaan dapat melakukan aktivitasnya secara maksimal, meskipun semua peralatan modern yang diperlukan telah tersedia. Tenaga kerja diharapkan dapat bekerja lebih produktif dan profesional dengan didorong oleh rasa aman dalam melakukan segala aktivitasnya. Untuk meningkatkan produktivitas para tenaga kerja, maka diperlukan penghargaan serta pengakuan keberadaan para tenaga kerja tersebut.

Setiap perusahaan atau instansi pemerintah dalam melakukan aktifitasnya pasti memiliki tujuan- tujuan tertentu yang hendak dicapai. Untuk mewujudkan tujuan tersebut setiap perusahaan/instansi harus pandai dalam memilih strategi yang utamanya untuk melakukan perencanaan sumber daya manusia, pada intinya terfokus pada langkah-langkah tertentu yang diambil oleh manajer atas tersedianya tenaga kerja yang tepat untuk mencapai tujuan dan berbagai sasaran yang telah ditetapkan. Salah satu faktor yang berpengaruh 
terhadap pencapaian tujuan organisasi adalah pengalaman kerja.

Istilah pengalaman digunakan untuk merujuk pada pengetahuan dan keterampilan tentang sesuatu yang diperoleh lewat keterlibatan atau berkaitan dengannya selama periode tertentu. Secara umum, pengalaman menunjuk kepada mengetahui bagaimana atau pengetahuan prosedural, daripada pengetahuan proposional, sedangkan menurut Kreitner dan Kinicki (2004) menyatakan bahwa. Masa kerja yang lama akan cenderung membuat seorang pegawai lebih merasa betah dalam suatu organisasi, hal ini disebabkan diantaranya karena telah beradaptasi dengan lingkungannya yang cukup lama sehingga seorang pegawai akan merasa nyaman dengan pekerjaannya.

Upaya pencapaian tujuan organisasi tak terlepas dari motivasi kerja yang dimiliki pegawai. Motivasi didefinisikan sebagai keadaan dalam pribadi seseorang yang mendorong keinginan individu untuk melaksanakan kegiatan- kegiatan dalam pencapaian tujuan (Hasibuan, 2003). Pemberian motivasi juga berarti memberikan kesempatan pada pegawai untuk mampu mengembangkan kemampuannya dan merupakan dorongan semaksimal mungkin pegawai untuk berbuat atau berproduksi dengan begitu kinerja pegawai akan lebih baik.

Dinas Perumahan dan Permukiman Kabupaten Lampung Selatan dalam upaya mencapai tujun organisasi menunut pegawai harus beradaptasi dengan tugas dan tanggungjawab yang baru. Berdasarkan observasi yang dilakukan penulis di temukan masih banyak pegawai Dinas Perumahan Dan Permukiman yang belum memiliki pengalaman di bidang masing-masing yang berdampak pada kurang maksimalnya kinerja pegawai, hal ini disebabkan karena masih mempelajari tugas-tugas yang baru.
Pegawai Dinas Perumahan Dan Permukiman Kabupaten Lampung Selatan yang telah berpengalaman memberikan motivasi kepada pegawai yang belum berpengalaman sehingga dapat mengembangkan kemampuannya dan dapat mendorong semaksimal mungkin untuk dapat bekerja sebaik mungkin itupun apabila pegawai tersebut mempunyai motivasi yang kuat. Penulis melihat masih banyak pegawai tidak memiliki motivasi yang tinggi, di lihat dari kinerja pegawai yang kurang maksimal masih banyak pegawai yang hanya datang tapi tidak mempelajari tugas-tugas utamanya.

Berdasarkan data diketahui sebanyak 2 $(3,12 \%)$ orang pegawai memiliki masa kerja 0-1 tahun, sebanyak $13(20,31)$ pegawai memiliki masa kerja $2-3$ Tahun, sebanyak $21(42,19 \%)$ memiliki masa kerja 4-5 tahun, sebanyak 10 $(12,5 \%)$ memilkiki masa kerja 6 - 20 tahun dan sebanyak 14 orang memiliki masa kerja selama 21 - 31 tahun. Oleh Karena itu untuk mencapai suatu tujuan maka harus sesuai dengan kemampuan untuk mengetahui kebutuhan para pegawai, dengan kata lain bahwa pengalaman kerja yang dilaksanakan itu harus sesuai dengan teknik-teknik motivasi kerja.

Berdasarkan uraian di atas, peneliti tertarik untuk meneliti permasalahan tersebut dengan judul: “ Pengaruh Pengalaman Kerja Terhadap Motivasi Kerja Pegawai Pada Dinas Perumahan Dan Permukiman Kabupaten Lampung Selatan".

\section{KAJIAN TEORI}

\section{Pengertian Pengalaman Kerja}

Pengalaman dalam semua kegiatan sangat diperlukan, karena experience is the best teacher, pengalaman guru yang terbaik. Maksud dari hal tersebut adalah bahwa seseorang belajar dari pengalaman 
yang pernah dialaminya. Menurut Kamus Bahasa Indonesia (Depdiknas, 2005), "pengalaman dapat diartikan sebagai yang pernah dialami (dijalani, dirasa, ditanggung, dsb)".

Dari uraian di atas dapat kita simpulkan bahwa pengalaman kerja seseorang menunjukkan jenis-jenis pekerjaan yang telah dilakukan seseorang dan memberikan peluang besar bagi seseorang untuk melakukan pekerjaan yang lebih baik. Karena semakin luas pengalaman kerja seseorang, maka semakin trampil seseorang dalam melakukan pekerjaan dan semakin sempurna pula pola berpikir dan sikap dalam bertindak untuk mencapai tujuan yang telah ditetapkan.

Adapun menurut hukum (law of exercise) dalam Mustaqim (2004) diungkapkan bahwa dalam law of exercise atau the law disuse (hukum penggunaan) dinyatakan bahwa "Hubungan antara stimulus dan respon akan bertambah kuat atau erat bila sering digunakan (use) atau sering dilatih (exercise) dan akan berkurang, bahkan lenyap sama sekali jika jarang digunakan atau tidak pernah sama sekali".

Elaine B Johnson (2007) menyatakan bahwa "pengalaman memunculkan potensi seseorang. Potensi penuh akan muncul bertahap seiring berjalannya waktu sebagai tanggapan terhadap bermacam-macam pengalaman". Pengalaman akan membentuk pengetahuan dan ketrampilan serta sikap yang lebih menyatu pada diri seseorang, jika bidang pekerjaan yang ditangani selama masih bekerja merupakan bidang yang sejenis yang pada akhirnya akan membentuk spesialisasi pengalaman kerja diperoleh selama seseorang bekerja pada suatu perusahaan dari mulai masuk hingga saat ini. Selain itu pengalaman dapat diperoleh dari tempat kerja sebelumnya yang memiliki bidang pekerjaan yang sama dengan yang sedang dihadapi.
Banyak sedikitnya pengalaman kerja akan menentukan atau menunjukan bagaimana kualitas dan produktivitas seseorang dalam bekerja, artinya mudah sukarnya atau cepat lambatnya seseorang dalam mengerjakan suatu pekerjaan akan dipengaruhi oleh seberapa banyak Pengalaman kerja mempunyai pengaruh terhadap banyaknya produksi, besar kecilnya dan efisiensi yang dapat dilihat dari hasil produksi tenaga kerja yang diarahkan.

Dalam pengertian lain, pengalaman kerja juga dapat diperoleh dengan melewati masa kerja yang telah dilakukan disuatu tempat kerja. Pengalaman kerja seseorang dalam suatu pekerjaan yang di infestasikan dalam jumlah masa kerja akan meningkatkan kemampuan dan kecakapan kerja seseorang sehingga hasil kerja akan semakin meningkat.

Pengalaman kerja tidak hanya menyangkut jumlah masa kerja, tetapi lebih dari juga memperhitungkan jenis pekerjaan yang pernah atau sering dihadapi. Sejalan dengan bertambahnya pekerjaan, maka akan semakin bertambah pula pengatahuan dan keterampilan seseorang dalam bekerja. Hal tersebut dapat dipahami karena terlatih dan sering mengulang-ulang suatu pekerjaan sehingga kecakapan dan keterampilan semakin dikuasai secara mudah, tetapi sebelumnya tanpa latihan, pengalaman-pengalaman yang pernah dimiliki akan menjadi berkurang bahkan terlupakan.

\section{Faktor-faktor yang Mempengaruhi Pengalaman Kerja}

Menurut Foster (2001) ada beberapa hal untuk menentukan berpengalaman tidaknya seorang karyawan yang sekaligus sebagai indikator pengalaman kerja yaitu:

1. Lama waktu/masa kerja

Ukuran tentang lama waktu atau masa kerja yang telah ditempuh seseorang 
dapat memahami tugas-tugas suatu pekerjaan dan telah melaksanakan dengan baik.

2. Tingkat pengetahuan dan keterampilan yang dimiliki

Pengetahuan merujuk pada konsep, prinsip, prosedur, kebijakan atau informasi lain yang dibutuhkan oleh karyawan. Pengetahuan juga mencakup kemampuan untuk memahami dan menerapkan informasi pada tanggung jawab pekerjaan. Sedangkan ketrampilan merujuk pada kemampuan fisik yang dibutuhkan untuk mencapai atau menjalankan suatu tugas atau pekerjaan.

3. Penguasaan terhadap pekerjaan dan peralatan

Tingkat penguasaan seseorang dalam pelaksanaan aspek-aspek tehnik peralatan dan tehnik pekerjaan.

\section{Pengertian Motivasi}

Motivasi berasal dari kata latin "Movere" yang berarti dorongan atau daya penggerak. Motivasi berasal dari kata dasar motif yang berarti dorongan pada sifat manusia untuk bertindak atau bergerak dan secara langsung melalui saluran perilaku mengarah pada suatu tujuan yang telah disepakati dalam organisasi atau perusahaan.

Motivasi dalam manajemen ditunjukan pada sumber daya manusia umumnya dan bawahan khususnya. Motivasi mempersoalkan bagaimana cara mengarahkan daya dan potensi bawahan, agar mau bekerja sama secara produktif berhasil mencapai dan mewujudkan tujuan yang telah ditentukan. Pentingnya motivasi karena menyebabkan, menyalurkan, dan mendukung perilaku manusia, supaya pekerja mau bekerja giat dan antusias mencapai hasil yang optimal dalam suatu pekerjaannya. Motivasi semakin penting karena manajer membagikan pekerjaan pada bawahannya untuk dikerjakan dengan baik dan terintegrasi kepada tujuan yang diinginkan.

Perusahaan tidak hanya mengharapkan karyawan mampu berbicara dalam pekerjaan atau terampil dalam melakukan pekerjaanya tetapi yang terpenting mereka memiliki keinginan untuk bekerja dengan giat dan mencapai hasil kerja yang baik. Menurut Siagian (2002) motivasi adalah daya pendorong yang mengakibatkan seseorang anggota organisasi mau dan rela untuk mengerahkan kemampuan dalam bentuk keahlian dan ketrampilan, tenaga dan waktunya untuk menyelenggarakan berbagai kegiatan yang menjadi tanggung jawabnya dan menunaikan kewajibannya, dalam rangka pencapaian tujuan dan berbagai sasaran organisasi yang telah ditentukan sebelumnya.

Menurut Nawawi (2003) motivasi berarti suatu kondisi yang mendorong atau menjadi sebab seseorang melakukan suatu perbuatan atau kegiatan, yang berlangsung secara sadar. Stephen P. Robbins (2007) mendefinisikan bahwa motivasi sebagai satu proses yang menghasilkan suatu intensitas, arah, dan ketekunan individual dalam usaha untuk mencapai satu tujuan.

Jadi motivasi berdasarkan teori diatas dapat kita simpulkan bahwa motivasi merupakan suatu upaya yang dilakukan untuk mendorong karyawan dalam pencapaian suatu tujuan dalam organisasi yang dimana karyawan atau pekerja yang akan melakukan suatu tindakan untuk mencapai tujuan yang maksimal dalam perusahaan.

\section{Faktor-Faktor Yang Mempengaruhi Motivasi}

Memberikan motivasi kepada pegawai oleh pimpinannya merupakan proses kegiatan pemberian motivasi kerja, 
sehingga pegawai tersebut berkemampuan untuk pelaksanaan pekerjaan dengan penuh tanggung jawab. Tanggung jawab adalah kewajiban bawahan untuk melaksanakan tugas sebaik mungkin yang diberikan oleh atasan, dan inti dari tanggung jawab adalah kewajiban (Siagian, 2001). Nampaknya pemberian motivasi oleh pimpinan kepada bawahan tidaklah begitu sukar, namun dalam praktiknya pemberian motivasi jauh lebih rumit. Siagian (2001) menjelaskan kerumitan ini disebabkan oleh:

1. Kebutuhan yang tidak sama pada setiap pegawai, dan berubah sepanjang waktu. Disamping itu perbedaan kebutuhan pada setiap taraf sangat mempersulit tindakan motivasi para manajer. Dimana sebagian besar para manajer yang ambisius, dan sangat termotivasi untuk memperoleh kepuasan dan status, sangat sukar untuk memahami bahwa tidak semua pegawai mempunyai kemampuan dan semangat seperti yang dia miliki, sehingga manajer tersebut menerapkan teori coba-coba untuk menggerakkan bawahannya.

2. Feeling dan emotions yaitu perasaan dan emosi. Seseorang manajer tidak memahami sikap dan kelakuan pegawainya, sehingga tidak ada pengertian terhadap tabiat dari perasaan, keharusan, dan emosi.

3. Aspek yang terdapat dalam diri pribadi pegawai itu sendiri seperti kepribadian, sikap, pengalaman, budaya, minat, harapan, keinginan, lingkungan yang turut mempengaruhi pribadi pegawai tersebut.

4. Pemuasan kebutuhan yang tidak seimbang antara tanggung jawab dan wewenang. Wewenang bersumber atau datang dari atasan kepada bawahan, sebagai imbalannya pegawai bertanggung jawab kepada atasan, atas tugas yang diterima. Seseorang dengan kebutuhan akan rasa aman yang kuat mungkin akan "mencari amannya saja", sehingga akan menghindar menerima tanggung jawab karena takut tidak berhasil dan diberhentikan dan di lain pihak mungkin seseorang akan menerima tanggung jawab karena takut diberhentikan karena alasan prestasi kerja yang jelek (buruk).

\section{METODE PENELITIAN}

\section{Objek Penelitian}

Objek penelitian dalam proposal ini adalah Pengalaman Kerja dan motivasi kerja di Dinas Perumahan dan Pemukiman Kabupaten Lampung Selatan yang beralamat di jalan Mustofa Kamal Nomor 21 Lampung Selatan. Penelitian dilaksanakan pada bulan April sampai Juli 2016.

\section{Metode dan Teknik Pengumpulan Data}

Dalam penelitian ini jenis data yang diperlakukan adalah :

a. Data Primer Data primer merupakan data dasar yang akan diperoleh langsung tanpa perantara orang atau lembaga lain sebagai pihak ketiga. Data primer ini diperoleh dengan wawancara melalui responden dengan menggunakan daftar pertanyaan.

b. Data Sekunder Data skunder merupakan data yang diperoleh melalui orang lain yang berhubungan dengan permasalahan yang dipecahkan. Data sekunder ini diperoleh melalui cara studi dokumenter yaitu mengumpulkan dan mempelajari brosur-brosur serta dokumen organisasi. 
Langkah-langkah pengumpulan data yang penulis lakukan dengan mengadakan penelitian lapangan, adapun teknik yang digunakan dalam pengumpulan data adalah dengan :

1. Observasi, yaitu mengadakan survey atau pengamatan langsung kelokasi penelitian.

2. Interview atau wawancara, yaitu mengadakan tanya jawab langsung dengan pegawai.

3. Dokumentasi, yaitu mengumpulkan dan mencatat dokumentasi yang relevan.

4. Kuisioner, yaitu membuat pertanyaan yang berhubungan dengan varibael penelitian.

\section{Sampel dan Populasi}

Menurut Arikunto (2006) sampel adalah sebagian atau wakil populasi yang diteliti. Pengambilan sampel harus dilakukan sedemikian rupa sehingga diperoleh sampel yang benar-benar berfungsi sebagai sampel. Apabila subjek kurang dari 100 orang maka pengambilan sampel semuanya, apabila lebih dari 100 maka diambil $10-15 \%$ atau $20-25 \%$. Berdasarkan pernyataan Arikunto diatas, maka penulis menjadikan keseluruhan pegawai sebagai sampel, dikarenakan jumlah pegawai Dinas Perumahan dan Pemukiman Lampung Selatan sebanyak 60 pegawai maka penulis mengambil seluruh karyawan untuk dijadikan sampel.

\section{Metode Analisis Data}

Analisis kualitatif adalah analisis yang menggambarkan secara rinci, dengan interpretasi terhadap data yang diperoleh melalui pendekatan teoritis.

Analisis kuantitatif ialah metode analisis dengan angka-angka yang dapat dihitung maupun diukur, dan dalam prosesnya menggunakan alat bantu statistic (Algifari, 2003).
Persamaan Regresi Linear Sederhana menentukan persamaan regresi linear sederhana untuk X :

$$
Y=a+b X+e
$$

Keterangan:

$$
\begin{aligned}
& \mathrm{Y}=\text { Motivasi kerja } \\
& \mathrm{a}=\text { Konstanta } \\
& \mathrm{b}=\text { Koefisien regresi } \mathrm{X} \\
& \mathrm{X}=\text { Pengalaman kerja } \\
& \mathrm{e}=\text { Faktor kesalahan }
\end{aligned}
$$

Untuk mengetahui besarnya pengaruh, penghitungan koefisien korelasi tersebut kemudian dilanjutkan dengan Rumus Koefisien Determinasi atau Koefisien Penentu (KP):

$$
K P=(r)^{2} x 100 \%
$$

Untuk menguji secara hipotesis secara parsial digunakan Uji t dengan rumus :

$$
t_{\text {hitung }}=\frac{r \sqrt{N-2}}{\sqrt{1-r^{2}}}
$$

Keterangan:

$$
\begin{array}{ll}
\mathrm{t}_{\text {hitung }} & =\text { Nilai } \mathrm{t} \\
\mathrm{r} & =\text { Koefisien Korelasi } \\
\mathrm{N} & =\text { Jumlah responden }
\end{array}
$$

Kriteria untuk Uji $\mathrm{t}$ adalah sebagai berikut :

a) Jika $t_{\text {hitung }}>t_{\text {tabel }}$ maka Ha diterima dan Ho ditolak.

b) Jika $\mathrm{t}_{\text {hitung }} \leq \mathrm{t}$ tabel maka Ha ditolak dan Ho diterima.

\section{HASIL DAN PEMBAHASAN}

\section{Analisis Kualitatif}

Berdasarkan hasil angket tentang pengalaman kerja diperoleh hasil sebanyak 29 responden $(47,67 \%)$ menjawab sangat 
setuju dengan pegawai yang memiliki pengalaman kerja, sebanyak 24 responden $(40,67 \%)$ menjawab setuju dengan pengalaman dan kemampuan kerja pegawai, dan sisanya sebanyak 7 responden $(11,67 \%)$ menjawab kurang setuju hal imi disebabkan karena pengalaman kerja tidak menjamin pegawai mampu bekerja dengan lingkungan yang baru.

Berdasarkan hasil angket tentang motivasi kerja yang terdiri atas beberapa indikator kebutuhan fisik, kebutuhan rasa aman, kebutuhan sosial, kebutuhan akan penghargaan dan kebutuhan aktualisasi diri diperoleh hasil sebagai berikuat :Sebanyak 29 responden (49\%) menjawab sangat setuju, sebanyak 26 responden (43\%) menjawab setuju dan sissanya sebanyak 5 responden $(8 \%)$ menjawab kurang setuju dengan motivasi kerja pegawai di Dinas Perumahan dan Permukiman Kabupaten Lampung Selatan.

\section{Analisis Kuantitatif}

Hasil koefisien arah regresi antara pengalaman kerja terhadap motivasi kerja sebesar 0.395 dengan konstanta sebesar 26.899. Dengan demikian, persamaan regeresinya adalah $\mathrm{Y}=26.899+0.395 \mathrm{X}+\mathrm{e}$. Persamaan regresi tersebut terlihat bahwa pengaruh pengalaman kerja terhadap motivasi kerja pegawai adalah searah (positif), hal tersebut ditunjukkan pada koefisien regresi dalam persamaan regresi tersebut yang menunjukkan angka positif sebesar 0,395 yang mengandung arti bahwa setiap kenaikan pengalaman kerja 1 satuan akan diikuti dengan kenaikan motivasi kerja pegawai Dinas Perumahan dan Permukiman Lampung Selatan.

Nilai t hitung variabel pengalaman kerja yaitu 3.364 dengan konstanta 5.248 pada $\mathrm{t}$ tabel dengan $\mathrm{db} 60$ dan taraf signifikan 0,05 diperoleh 1.671 karena $\mathrm{t}$ hitung > $\mathrm{t}$ table maka Ha diterima. Signifikasi variabel Pengalaman kerja adalah 0.000 yang berarti probabilitas 0.00 , karena probabilitas kurang dari 0,05 maka Ha diterima. artinya Pengalaman kerja berpengaruh positif terhadap motivasi kerja pegawai Dinas Perumahan dan Permukiman Kabupaten Lampung Selatan.

Koefisien Determinasi diketahui bahwa Kontribusi ( $R$ Square ) sebesar 0.163 artinya sebesar $16,3 \%$ variasi perubahan variabel motivasi kerja mampu dijelaskan oleh variabel pengalaman kerja sedangkan sisanya $83,7 \%$ lagi dijelaskan oleh variabel lain diluar dari variabel penelitian ini.

Motivasi itu penting karena motivasi menyebabkan, menyalurkan, dan mendukung perilaku manusia supaya karyawan mau bekerja giat dan antusias mencapai hasil yang optimal dalam suatu pekerjaannya. Motivasi semakin penting karena manajer membagikan pekerjaan pada bawahannya untuk dikerjakan dengan baik dan terintegrasi kepada tujuan yang diinginkan. Perusahaan tidak hanya mengharapkan karyawan mampu berbicara dalam pekerjaan atau terampil dalam melakukan pekerjaannya tetapi yang terpenting mereka memiliki keinginan untuk bekerja dengan giat dan mencapai hasil kerja yang baik.

\section{KESIMPULAN DAN SARAN}

\section{Kesimpulan}

Berdasarkan hasil penelitian diperoleh kesimpulan bahwa hasil pengujian hipotesis pengaruh pengalaman kerja (X) terhadap Motivasi kerja (Y) secara parsial menunjukan bahwa Nilai t hitung variabel pengalaman kerja yaitu 3.364 dan $t$ tabel 1.671 karena $\mathrm{t}$ hitung $>\mathrm{t}$ tabel maka $\mathrm{Ha}$ diterima. artinya Pengalaman kerja berpengaruh positif terhadap motivasi kerja pegawai Dinas Perumahan dan Permukiman Kabupaten Lampung Selatan. Kontribusi ( $R$ Square ) sebesar 0.163 
artinya sebesar $16,3 \%$ variasi perubahan variabel motivasi kerja mampu dijelaskan oleh variabel pengalaman kerja.

\section{Saran}

Berdasarkan uraian di atas, penulis mengajukan saran-saran sebagai berikut:

1. Dari hasil penelitian menunjukkan bahwa terdapat pengaruh positif dan signifikan, artinya kondisi sumber daya manusia berdampak positif, sehingga Dinas Perumahan dan Permukiman Lampung Selatan diharapkan dapat mempertahankan kinerja karyawan yang dimiliiki agar dapat mengahsilkan produktivitas kerja pegawai yang lebih baik.

2. Bagi penelitian selanjutnya diharapkan dapat meneliti dengan variabelvariabel lain diluar variabel ini agar memperoleh hasil yang lebih bervariatif yang dapat menggambarkan hal-hal apa saja yang berpengaruh terhadap produktivitas kerja dan disarankan untuk memperluas cakupan penelitian tentang pengaruh motivasi dan pengalaman kerja.

\section{DAFTAR PUSTAKA}

Ahmadi, Djauzak. 2004. Peningkatan Mutu Pendidikan Sebagai Sarana Pembangunan Bangsa. Jakarta: Balai Pustaka.

Ishak, Arep. 2003. Manajemen Motivasi. Jakarta: PT. Grasindo.

Armstrong, Michael. 2009. Armstrong's Handbook of Human Resource Management Practice. London: Kogan Page.
Foster, B. S., dan R. Karen. 2001. Pembinaan Untuk Meningkatkan Kinerja Karyawan. Jakarta: PPM.

Gomes, Faustino Cardoso. 2003. Manajemen Sumber daya Manusia. Yogyakarta: Penerbit Andi.

Heidjrachman dan Suad Husnan. 2002. Manajemen Personalia, edisi kelima, cetakan kesepuluh. Yogyakarta: BPFE.

Malayu, P. Hasibuan. 2004. Manajemen Sumber Daya Manusia. Cetakan ke Tujuh, edisi revisi. Jakarta: Bumi Aksara.

Nawawi, Hadari. 2003. Manajemen Sumber Daya Manusia untuk Bisnis Yang Kompetitif, Cetakan Kedua. Yogyakarta: UGM Press.

Ravianto, J. 1986. Produktivitas dan Tenaga Kerja Indonesia. Jakarta: Lembaga Informasi Usaha dan Produktivitas.

Robbins. P.S. 2002. Prisip-Prinsip Perlaku Organisasi. Edisis kelima. Jakarta: Erlangga.

Sedarmayanti. 2001. Sumber Daya Manusia dan Produktivitas Kerja, cetakan kedua. Bandung: Mandar Maju.

Siagian. 2002. Kiat-Kiat Meningkatkan Produktivitas Kerja. Jakarta: Rineka Cipta.

Sondong, P. Siagian. 2001. Manajemen Sumber Daya Manusia. Jakarta: Bumi Aksara.

Sugiyono. 2004. Metode Penelitian Administrasi, cetakan ketujuh. Bandung: Alfabeta. 